\title{
Diel vertical migration patterns of three zooplankton populations in a Chilean lake
}

\author{
Patrones de migración vertical de tres poblaciones de zooplancton en un lago chileno

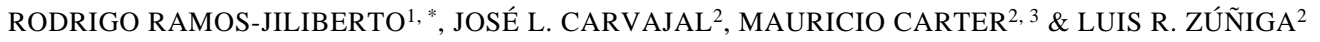 \\ ${ }^{1}$ Departamento de Ciencias Ecológicas, Facultad de Ciencias, Universidad de Chile, Casilla 653, Santiago, Chile \\ ${ }^{2}$ Instituto de Biología, Universidad Católica de Valparaíso, Casilla 4059, Valparaíso, Chile \\ ${ }^{3}$ Present address: Departamento de Ecología, Facultad de Ciencias Biológicas, \\ P. Universidad Católica de Chile, Casilla 114-D, Santiago, Chile \\ *Corresponding author: e-mail: roramos@uchile.cl
}

\begin{abstract}
In this work we analyzed the depth-distribution, at noon and midnight, of three zooplankton populations which are common inhabitants of lakes from central Chile and coexist in lake El Plateado. The species were Tumeodiaptomus diabolicus, Diaphanosoma chilense and Bosmina longirostris. Also, we analyzed the association between the depth-specific abundances of the groups and the depth-specific temperature and oxygen values during the sampling period. Our results show that: (1) the three population exhibited diel vertical migration during part of the year; (2) T. diabolicus and D. chilense exhibited the normal pattern of vertical migration, and $B$. longirostris presented both the normal and the reverse pattern; (3) for all species and most dates, zooplankters experience significant decreases in oxygen exposure as a consequence of downward migration. Temperature costs are less important but present in T. diabolicus and D. chilense during part of the year.
\end{abstract}

Key words: depth-selection, Cladocera, Copepoda, reverse vertical migration, Chile.

\section{RESUMEN}

En este trabajo analizamos la distribución en profundidad, a mediodía y medianoche, de tres poblaciones de zooplancton que son habitantes comunes de los lagos de Chile central, y que coexisten en el lago El Plateado. Las especies fueron Tumeodiaptomus diabolicus, Diaphanosoma chilense y Bosmina longirostris. También analizamos la asociación entre las abundancias profundidad-específicas de los grupos y los valores profundidad-específicos de temperatura y oxígeno durante el periodo de muestreo. Nuestros resultados muestran que: (1) las tres poblaciones exhibieron migración vertical durante una parte del año; (2) T. diabolicus y D. chilense exhibieron el patrón normal de migración, y B. longirostris presentó tanto el patrón normal como el inverso; (3) para todas las especies y en la mayoría de las fechas, el zooplancton presentó reducciones significativas en su exposición al oxígeno como consecuencia de la migración descendente. Los costos térmicos son menos importantes pero existentes en $T$. diabolicus y $D$. chilense durante parte del año.

Palabras clave: selección de profundidad, Cladocera, Copepoda, migración vertical inversa, Chile.

\section{INTRODUCTION}

Diel vertical migration (DVM) can be considered as a special form of depth-selection behavior of individuals (De Meester et al. 1999), and being a widely-occurring phenomenon in freshwater and marine zooplankton, it is most pronounced in thermally-stratified lakes (Hutchinson 1967, Lampert 1989). There is agreement in that DVM is a predator-avoidance strategy (Zaret \& Suffern 1976, Stich \& Lampert 1981, 1984, but see also Lampert et al. 1988, Lampert 1989,
Guisande et al. 1991, Gabriel 1993, De Meester et al. 1999), and that this response is plastic and inducible, i.e., the presence of a predatorreleased chemical cue is necessary to trigger the behavioral response (Ringelberg 1991, Frost \& Bollens 1992, Loose \& Dawidowicz 1994, Von Elert \& Loose 1996, De Meester et al. 1999). Two basic modes of DVM are described in the literature (Lampert 1989). A first mode corresponds to the "normal" pattern, with an ascending movement of individuals at dusk and a descending movement at dawn. A second mode of DVM is the opposite, which is 
called "reverse" vertical migration. While vertebrate predators (mainly fish) are known to trigger the normal vertical migration response, invertebrate predators stimulate the reverse migration. The specific quantitative pattern varies largely from system to system (Hutchinson 1967), in terms of amplitude of the population displacement, and the frequency-distribution of zooplankters during day and night.

In temperate freshwater lakes, the vertical spatial structure normally involves steep gradients of light and temperature, defining two sub-environments whose physical conditions differ strongly, namely a superficial, less-dense water layer that is well-illuminated during daytime and presents a higher and nearhomogeneous temperature, and a deep, moredense, dark and cool water layer, where the accumulation of detritus and oxidative processes take place. Therefore, zooplankters exhibit normal DVM if they locate in the hypolimnetic refuge during day, avoiding in this way the illuminated and risky epilimnion. If invertebrate carnivorous, which are themselves predated by fish, are present in the lake; we expect they perform normal DVM avoiding fish predation, and the herbivorous zooplankters perform reverse DVM avoiding carnivorous plankton.

Regarding the wide spectrum of specific modes of DVM over many different taxa, populations and environments, it has been suggested that several physical, chemical and biological conditions of the water may modify the basic behavioral response (Calaban \& Makarewicz 1982, Geller 1986, Lampert et al. 1988, De Meester et al. 1999, Tollrian \& Dodson 1999). Likewise, internal status of the zooplankters (De Meester et al. 1999, Tollrian \& Dodson 1999), genetic differences of the populations (Boersma et al. 1998, De Meester et al. 1999) and predation types (Mangel \& Clark 1988, Frost \& Bollens 1992) are also important determinants of the specificity of DVM and other predator-mediated plastic traits.

While DVM is a behavioral strategy which allows zooplankters to diminish mortality rates, it also involves some demographic cost. It has been proposed that the most costly consequence of DVM is the reduction in developmental rates due to the exposition of the organisms to lower environmental temperatures in the hypolimnion (Dawidowicz 1994). Furthermore, reduced developmental rates imply a reduction in the population birth rate. Likewise, the common development of hypoxic hypolimnetic waters in eutrophic lakes, offers an additional source of physiological stress for zooplankters due to the hypoxic condition itself, and toxic substances produced by anaerobic metabolism such as sulphide (Massana et al. 1994, Hanazato 1992) which is highly toxic to invertebrates at the concentrations often found in nature (Griesharber et al. 1992). Thus, the final effect of DVM at the population level will depend on the balance between the benefit from increasing survival and the cost derived from exposure to hypolimnetic conditions. On the other hand, since the pattern of DVM exhibited by a given population determines the interaction with predators and with food, the population growth and community-level processes are functionally linked to DVM. Therefore, the knowledge of DVM patterns provides valuable field information about ecological features of organisms and populations.

In this work our goal is to analyze the depthselection behavior patterns exhibited in an eutrophic lake by a group of coexisting herbivorous planktonic crustaceans, and the association between the observed vertical distribution of the zooplankters with water temperature and oxygen concentration. The three species considered in this work (following Araya \& Zúñiga 1985) are Tumeodiaptomus diabolicus (Copepoda), Bosmina longirostris (Cladocera), and Diaphanosoma chilense (Cladocera). These three groups together account for more than $95 \%$ of the total abundance of the herbivore crustacean plankton in the site of study (data from this survey and older unpublished results). Particularly, we will test the following hypotheses: (1) the tree species exhibit DVM during a given period of the year, (2) the DVM exhibited correspond to the normal pattern, and (3) the downward migration significantly decreases the temperature and oxygen level which zooplankters experience.

\section{MATERIAL AND METHODS}

\section{Data collection}

El Plateado is a warm-monomictic and eutrophic small lake (Montecino \& Cabrera 1984) located at $33^{\circ} 04^{\prime} 30^{\prime \prime} \mathrm{S}$ and $71^{\circ} 39^{\prime} 12^{\prime \prime}$ $\mathrm{W}$ at $340 \mathrm{~m}$ of altitude, between coastal hills at the southern end of Valparaíso, Chile. Chemical and physical characterization of this lake can be found in Dominguez et al. (1976, 1981) and Ramos-Jiliberto et al. (1997). The crustacean plankton of El Plateado is studied in Ramos-Jiliberto et al. (1998).

Temperature and dissolved oxygen concentration were recorded weekly, by using 
WTW OXI 196 equipment with a calibrated WTW EOT 196 submergible probe. Readings were made every $0.5 \mathrm{~m}$ from surface to the bottom and back, and the mean value was used. All measurements were made at noon, on the same station where the plankton samples were taken.

Sampling for the analyses of vertical distribution was made both at noon and midnight during the following dates: April 22, July 21, August 05, September 9, October 7, December 16 of 1995, and January 29 of 1996. The samples were taken from the pelagic area by using a $30 \mathrm{~L}$ Schindler sampler at depths of 0,1 , $2,3,4,5,7$, and $8.5 \mathrm{~m}$. For each depth, samples were collected from three different points, linearly arranged every $25 \mathrm{~m}$ along the major axis (North-South) of the lake, and stored as a single sample. This procedure allowed to increase the number of organisms per sample and to broaden the sampling area. Zooplankton samples were fixed in the field with a sugarformalin solution (Haney \& Hall 1973). In the laboratory, a known fraction of each sample was taken using a Folson-subsampler for subsequent counting under a WILD M5 stereomicroscope. Counting was made according to standard procedures (McCauley 1984).

\section{Statistical analyses}

Mean depth of zooplankton distributions was calculated as the average of the sampling depths, weighted by the relative abundance of the populations. This is given by

$$
Z=\sum_{i=0}^{8.5} \frac{z_{i} N_{i}}{n}
$$

where $z$ is the sampling depth, $N_{i}$ is the density of a population at depth $i$, and $n=\sum_{i=0}^{8.5} N_{i}$ is the total abundance of the population over depth in a given time. For descriptive purposes, the dispersion of each vertical distribution was calculated as the central $75 \%$ of the total abundance. This was done by fitting the cumulative relative abundances $(F)$ over depth, from surface to bottom, to the sigmoid model

$$
F=\frac{1}{1+e^{\alpha-\beta \log z}}
$$

where $e$ is the base of natural logarithms, $z$ is depth, and $\alpha$ and $\beta$ are fitting parameters. The depth at which 12.5 and $87.5 \%$ of the population is found, were then obtained algebraically.
The comparison of day vs. night zooplankton vertical distributions was done by using the method introduced by Solow et al. (2000) which is a permutation version of the KolmogorovSmirnov test. Random variables and Monte Carlo routines were generated with the software Poptools 2.4 (Hood 2002). The number of random permutations per test was estimated a priori (see results). A significant $(\mathrm{P}<0.05)$ difference between day and night distributions is interpreted as a strong evidence of DVM.

The association between the vertical distribution of zooplankters and environmental variables was tested with randomization methods of multiple regression analysis (Manly 1997), where the Y-values were randomized. We used 5,000 randomizations for each test, following the results of Manly (1997).

An assessment of the magnitude of the costs associated with the observed DVM was made through calculating the relative change (between day and night) of the weighted-average temperature and oxygen levels experienced by zooplankton populations. Statistical significance of that changes were tested by randomization procedures. First, the day and night relative abundances were pooled for each depth and split at random between day and night. Then, the new weighted-average temperature and oxygen levels were calculated and the statistic

$$
\theta=\frac{\theta_{D}-\theta_{N}}{\theta_{1}}
$$

was recorded, where $\theta_{D}, \theta_{N}$, and $\theta_{1}$ represent respectively the weighted-average temperature (or oxygen concentration) at day, night, and at $1 \mathrm{~m}$ depth as a reference. After 5,000 randomizations, the fraction of the differences lower (if $\theta_{\text {observed }}<0$ ) or larger (if $\theta_{\text {observed }}>0$ ) than the observed value $\theta_{\text {observed }}$ was used as the significance criterion at a 0.05 level (Manly 1997). In the case of temperature changes, we also expressed our results in terms of changes in birth rate. The calculation of birth rate change was done by means of the Paloheimo's method (Paloheimo 1974), and using the standard equations of Bottrell et al. (1976) for crustaceans in order to calculate the embryonic development time.

\section{RESULTS}

The vertical profiles of temperature and oxygen concentration at the dates of sampling are shown in Fig. 1. 

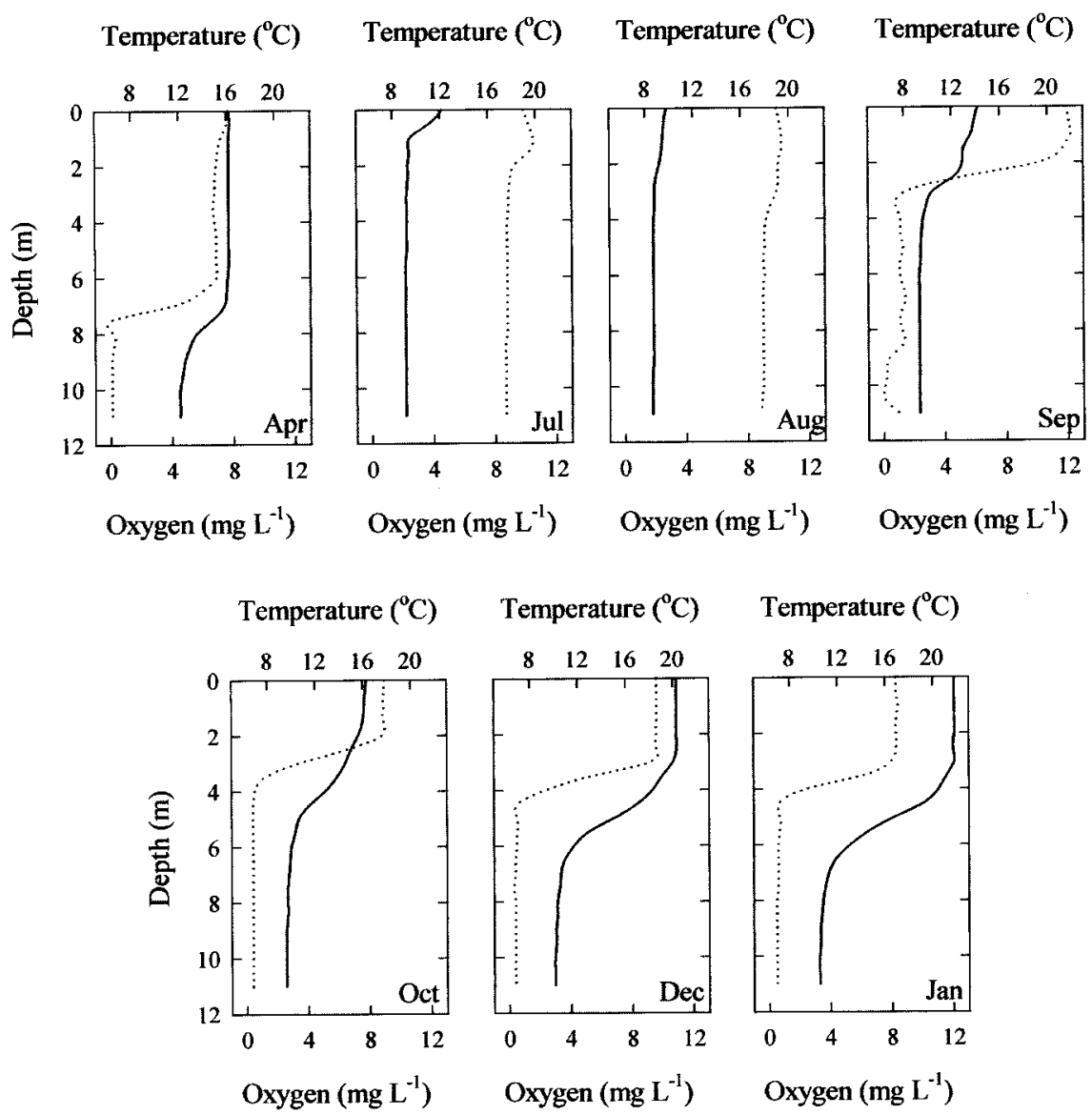

Fig. 1: Temperature and oxygen profiles of the site of study during the sampling dates. Continuous line and upper $\mathrm{x}$-axis show temperature; dotted line and bottom $\mathrm{x}$-axis show oxygen concentration.

Perfiles de temperatura y oxígeno del sitio de estudio durante las fechas de muestreo. Línea continua y eje-x superior muestran temperatura; línea punteada y eje-x inferior muestran concentración de oxígeno.

It can be noted that by the first sampling date (April) the thermal stratification is very weak, but there is still a deep anoxic layer. In July and August, the water column is well mixed, cool, and oxygenated. The stratification phase begins by September and becomes well established in December, where the upper layer of water is more than $20{ }^{\circ} \mathrm{C}$ and it is well aerated, but from 5-6 $\mathrm{m}$ to the lake bottom the water is severely hypoxic and cool.

The relative abundances of zooplankton over the vertical profile are shown in Table A-1 (Appendix 1). We neglected the occurrence of $D$. chilense prior to September, because its extremely low density. Before running the permutation analyses, the appropriate number of randomizations to be used was assessed numerically by performing several times the same test on a data set, and increasing the number of randomizations up to obtain convergent results. This is shown in Fig. 2, and it was found that at least 5,000 randomizations are required to get reliable results. Therefore we decided to perform 10,000 randomizations per test. The results of the tests of comparison between day and night vertical distributions are summarized in Table 1 , and a graphical display of the zooplankton distributions is shown in Fig. 3-5.

An analysis of Table 1 reveals that all three populations perform DVM during some period of the year. B. longirostris exhibit DVM from August to December, T. diabolicus from July to December, and D. chilense from September to December (Table 1, Fig. 3-5).

From Fig. 3 it can be seen that the mean depth of $T$. diabolicus is always deeper at daytime and shallower at night. The significance of the differences between day and 


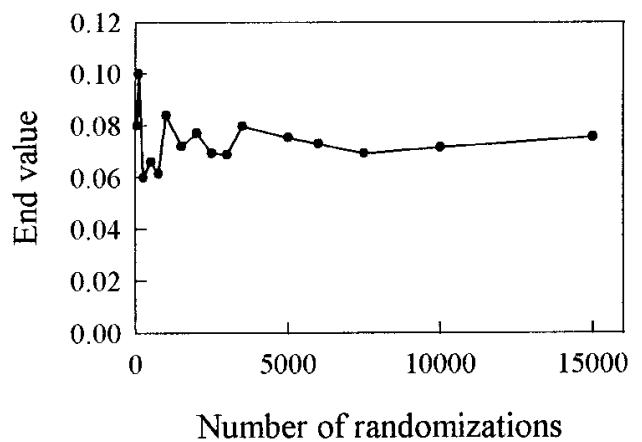

Fig. 2: Results (P-value) of the test of comparison of vertical distributions as a function of the number of randomizations used.

Resultados (valor-P) de la prueba de comparación de distribuciones verticales en función del número de aleatorizaciones utilizadas.

TABLE 1

Tests results for comparisons of day vs. night vertical distributions of plankton.

Asterisks indicate $\mathrm{P}<0.05$

Resultados de las pruebas de comparación de las distribuciones verticales de día vs. noche de plancton. Los asteriscos indican $\mathrm{P}<0,05$

\begin{tabular}{lccc}
\hline Date & T. diabolicus & B. longirostris & D. chilense \\
\hline April & 0.178 & 0.187 & \\
July & $0.011 *$ & 0.072 & \\
Agust & $0.036 *$ & $0.016 *$ & $0.032 *$ \\
September & $0.010 *$ & $0.013 *$ & $0.008 *$ \\
October & $0.039 *$ & $0.017 *$ & $0.002 *$ \\
December & $0.006 *$ & $0.040 *$ & 0.079 \\
January & 0.056 & 0.808 & \\
\hline
\end{tabular}

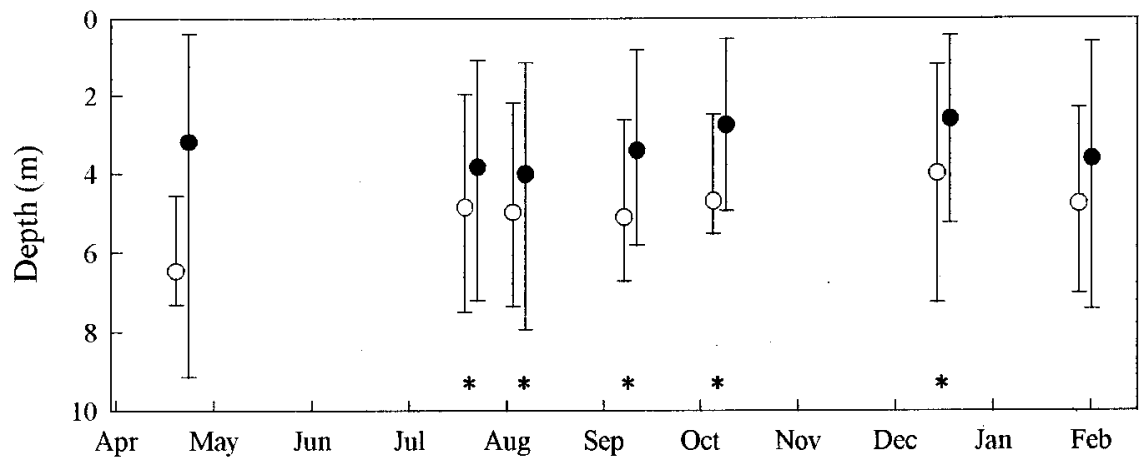

Fig. 3: Vertical distributions of T. diabolicus at noon (open circles) and midnight (closed circles). Circles indicate mean depth, and error bars show the depths inside which it is found the central 75 $\%$ of the group. Asterisks indicate significant differences between day and night.

Distribuciones verticales de $T$. diabolicus a mediodía (círculos abiertos) y medianoche (círculos cerrados). Los círculos indican la profundidad media, y las barras de error muestran las profundidades dentro de las cuales se encuentra el $75 \%$ central del grupo. Los asteriscos indican diferencias significativas entre día y noche. 


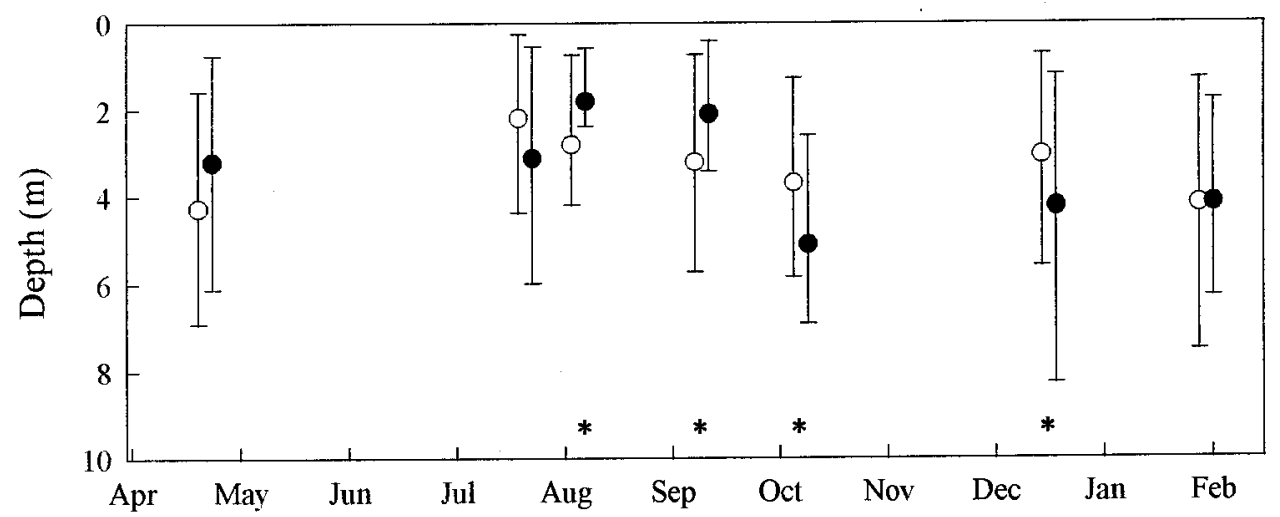

Fig. 4: Same as Fig. 3, for B. longirostris.

Lo mismo que Fig. 3, para B. longirostris.

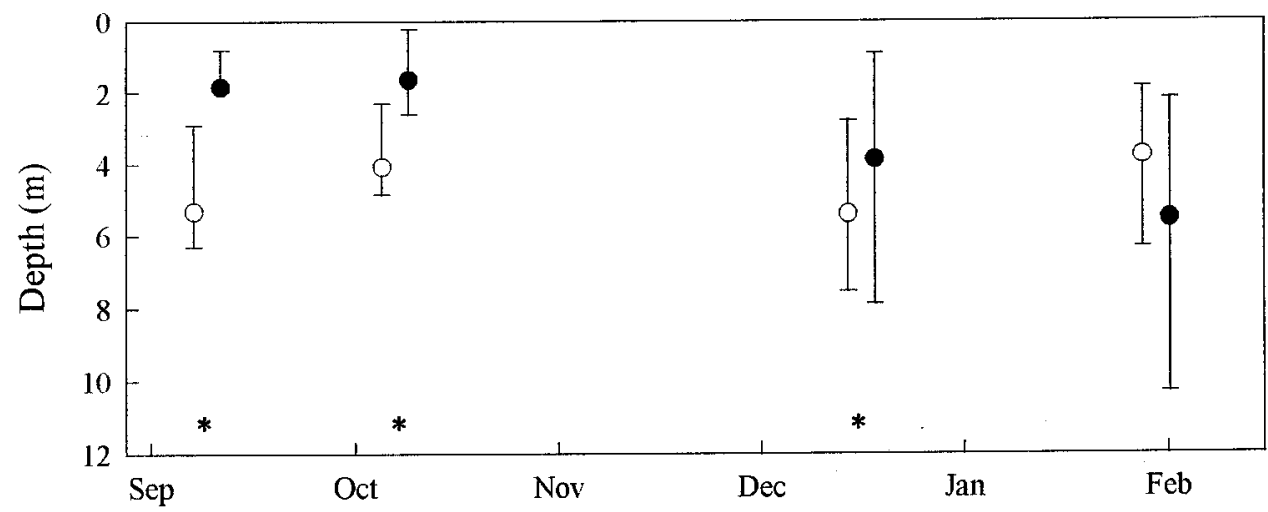

Fig. 5: Same as Fig. 3, for D. chilense.

Lo mismo que Fig. 3, para D. chilense.

night distributions of this population indicates that $T$. diabolicus performs (between July and December) the normal pattern of DVM. On the other hand, B. longirostris shows significantly different day/night distributions in four sampling dates (August-December), but the results indicate that this population exhibits normal DVM during August-September, whereas it performs reverse DVM during October-December (Fig. 4). Finally, D. chilense exhibits a normal DVM between September and December (Fig. 5).

Possible relationships between temperature and/or oxygen concentration and the zooplankton vertical distribution were analyzed by means of randomization-regression analyses (see methods). The data set was split, for each species, in two groups: one containing the cases where no DVM was detected, and the other group containing the cases where normal or reverse DVM was detected. Our results summarized in Table 2, indicate that when no DVM occurred, there was not any significant relationship between the target variables. On the other hand, when performing DVM, D. chilense abundance showed an inverse relation with oxygen during the day and a direct relation with the same variable during the night. The results are similar for T. diabolicus, since during the day an inverse relation with oxygen was also found, and during the night there was a direct relation with oxygen and temperature. The data of $B$. longirostris were further subdivided into two groups: the first one corresponds to the dates where zooplankters performed normal DVM, and the second group corresponds to the dates where they performed reverse DVM (see Table 2). No relation between abundance of $B$. longirostris and environmental variables was detected 
Summary of regression analyses for temperature and oxygen concentration versus depth-specific abundance of zooplankters: $\mathrm{D}=$ noon samples; $\mathrm{N}=$ midnight samples; $\mathrm{ns}=$ non-significant $($ at $5 \%$ level) results; $-\mathrm{ox}=$ significant inverse relation between oxygen level and abundance; +ox = significant direct relation between oxygen level and abundance; $+\mathrm{T}$ and $-\mathrm{T}$ analogous to +ox and -ox, but regarding water temperature.

Significant results refer to significance of regression coefficients

Resumen de los análisis de regresión para temperatura y concentración de oxígeno vs. abundancia profundidad-específica de los zooplanctontes: $\mathrm{D}=$ muestras de mediodía; $\mathrm{N}=$ muestras de medianoche; $\mathrm{ns}=$ resultados no-significativos (a nivel $5 \%) ;-o x=$ relación significativa inversa entre nivel de oxígeno y abundancia; +ox = relación significativa directa entre nivel de oxígeno y abundancia; +Y y -T análogo a +ox y -ox pero respecto a temperatura del agua. Resultados significativos se refieren a la significancia de los coeficientes de regresión

\begin{tabular}{|c|c|c|c|c|c|c|}
\hline & \multicolumn{2}{|c|}{ T. diabolicus } & \multicolumn{2}{|c|}{ B. longirostris } & \multicolumn{2}{|c|}{ D. chilense } \\
\hline & $\mathrm{D}$ & $\mathrm{N}$ & $\mathrm{D}$ & $\mathrm{N}$ & $\mathrm{D}$ & $\mathrm{N}$ \\
\hline No DVM & \multicolumn{2}{|c|}{$\mathrm{ns}$} & \multicolumn{2}{|c|}{ ns } & \multicolumn{2}{|c|}{ ns } \\
\hline Normal DVM & $-o x$ & $+\mathrm{ox} /+\mathrm{T}$ & $\mathrm{ns}$ & ns & $-o x$ & tox \\
\hline Reverse DVM & & & $\mathrm{ns}$ & $-o x$ & & \\
\hline
\end{tabular}

during normal DVM. During the time where $B$. longirostris performed reverse DVM, a significant relation was found only at night, where the abundance of zooplankters exhibited an inverse relation with oxygen concentration.

Our last analyses estimate, at each date, whether or not zooplankters experienced significant changes in their average exposure to temperature and oxygen levels as a consequence of their diel changes of vertical distribution. Figure 6 shows the relative temperature change (see methods section) experienced by the zooplankters and their associated change in birth rate. Negative values indicate a decrease of these parameters during day relative to night, and the asterisks indicate significant $(* *)$ or marginally significant $(*)$ differences. The same simbology applies for oxygen changes shown in Fig. 7. T. diabolicus exhibits significant diurnal reduction in average temperature and birth rate during September and October, and a marginally significant reduction during August. On the other hand, this species shows significant or marginally significant reductions in oxygen levels at all dates (see Fig. 7). Species B. longirostris show no significant diurnal changes in temperature/ birth rate in any date, but significant reduction in oxigen during April and September when is performing normal DVM. This species also shows significant diurnal increases in oxygen exposure during October and December due to the reverse DVM. Finally, D. chilense exhibits significant reduction in diurnal temperature/ birth rate and oxygen exposure during
September, and significant reduction in oxygen during October and December.

\section{DISCUSSION}

Ramos-Jiliberto \& Zúñiga (2001) analyzed the seasonal trends of DVM of Daphnia ambigua during the same field study. Those authors provided evidence that between July and September, D. ambigua exhibits normal DVM, and that temperature appears positively correlated, and oxygen inversely correlated with relative abundance of zooplankters. While Ramos-Jiliberto \& Zúñiga (2001) studied DVM of $D$. ambigua because its atypical population dynamics pattern, the present work provides information about DVM of the numerically dominant populations of lake El Plateado. These species are also common inhabitants of many lakes from central Chile.

Based on the significant differences between day and night vertical distributions of zooplankters, our results show that the three species studied here exhibit DVM. T. diabolicus showed a clear normal pattern between July and December, with the mean depth of population distribution located nearer the surface at night and closer to the lake bottom during the day. In agreement with the predator-avoidance hypothesis (Zaret \& Suffern 1976, Stich \& Lampert 1981, 1984, De Meester et al. 1999) as ultimate cause of DVM, we find vertebrate predators as an important component of this lake community. Silverside fish 


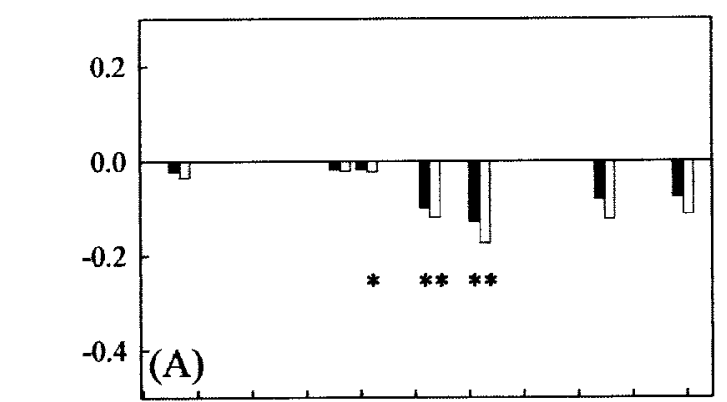

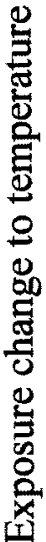

Apr May Jun Jul Aug Sep Oct Nov Dec Jan Feb

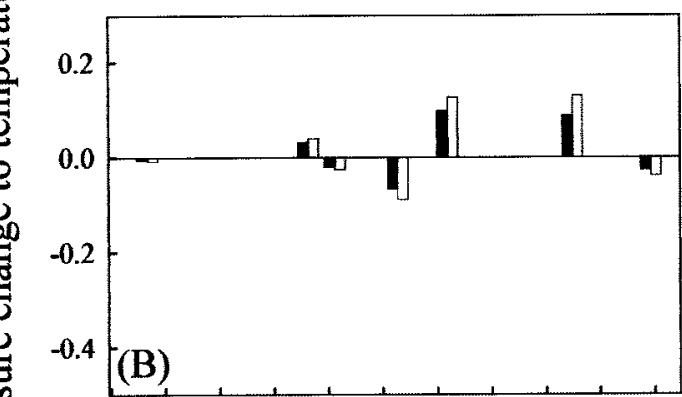

Apr May Jun Jul Aug Sep Oct Nov Dec Jan Feb

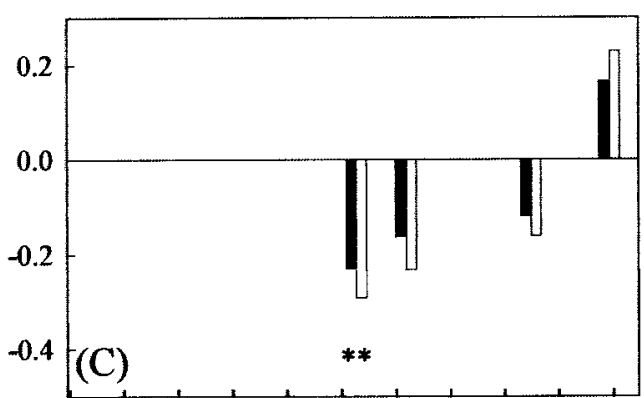

Apr May Jun Jul Aug Sep Oct Nov Dec Jan Feb

Fig. 6: Relative diurnal change in weightedaverage temperature (black bars) and birth rate (empty bars) of zooplankton. Significance estimated from 5,000 random permutations between day and night vertical distribution (see methods for details). (**) $\mathrm{P}<0.05 ;(*) 0.05<\mathrm{P}$ $<0.75$; (A) T. diabolicus, (B) B. longirostris, (C) D. chilense.

Cambio relativo diurno en el promedio ponderado de la temperatura (barras negras) y la tasa de nacimiento (barras vacías) del zooplancton. El nivel de significación fue estimado a partir de 5.000 permutaciones aleatorias entre las distribuciones verticales de día y noche (ver métodos para detalles). (**) $\mathrm{P}<0,05$; (*) $0,05<\mathrm{P}<0,75$; (A) T. diabolicus, (B) B. longirostris, (C) D. chilense.

Odontesthes bonariensis and Basilichthys sp. inhabit lake El Plateado since decades (LR Zúñiga \& R Ramos-Jiliberto unpublished results), and it is known to be zooplanktivorous

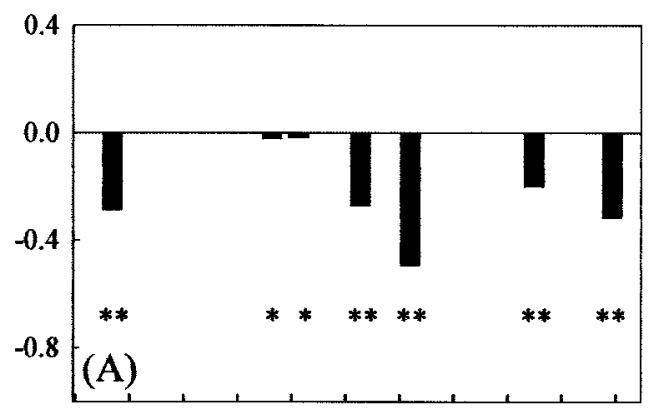

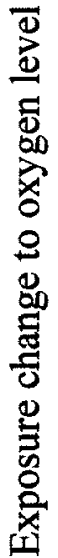

Apr May Jun Jul Aug Sep Oct Nov Dec Jan Feb

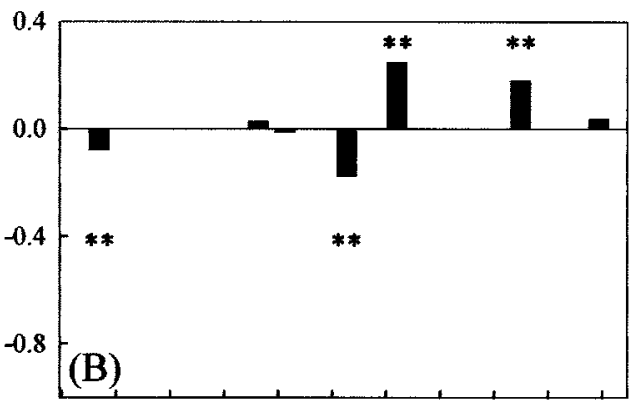

Apr May Jun Jul Aug Sep Oct Nov Dec Jan Feb

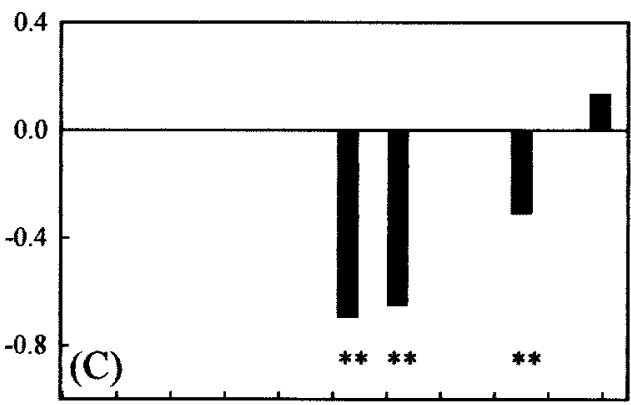

Apr May Jun Jul Aug Sep Oct Nov Dec Jan Feb

Fig. 7: Relative diurnal change in weightedaverage oxygen concentration for zooplankton. Significance estimated from 5,000 random permutations between day and night vertical distribution (see methods for details). (**) $\mathrm{P}<$ $0.05 ;(*) 0.05<\mathrm{P}<0.75$; (A) T. diabolicus, (B) B. longirostris, (C) D. chilense.

Cambio relativo diurno en el promedio ponderado de la concentración de oxígeno para el zooplancton. El nivel de significación fue estimado a partir de 5.000 permutaciones aleatorias entre las distribuciones verticales de día y noche (ver métodos para detalles). (**) $\mathrm{P}<0,05$; (*) $0,05<\mathrm{P}<0,75$; (A) T. diabolicus, (B) B. longirostris, (C) D. chilense.

during their juvenile stages (Burbridge et al. 1973, Bahamondes et al. 1979, Escalante 1983). The vertical distributions exhibited by $D$. chilense, from September to December, indicates also a normal DVM pattern during most of the free-living period for this species. 
The cladoceran B. longirostris exhibited a rather complex pattern. Significant differences between day and night distributions were detected between August and December, but the normal DVM pattern of August-September changes to the reverse DVM in October until December (Fig. 4). We are confident of our results for several reasons, especially because the high density and sampling sizes of $B$. longirostris throughout the year of study. Therefore, the observed switch from the normal to the reverse pattern of DVM should be explained by future research; nevertheless, it is possible to outline potential causes to this phenomenon. Reverse migration is known to be triggered by chemical cues released by nonvisually feeding invertebrate predators (Ohman \& Frost 1983, Lampert 1993). In lake El Plateado we have systematically observed (but not quantified) the presence of zooplanktivorous water mites, which reach high densities once the thermal stratification of the lake is established. Preliminary laboratory experiments have shown that these mites exert a high predation pressure on cladocerans, and therefore they are good candidates for being the stimulus, or the source of the stimulus, which induces the reverse DVM. Thermal stratification and the increase of water mite density in El Plateado often occur close to the observed time of change in DVM pattern (October); furthermore, B. longirostris are the smallest sized crustacean zooplankters inhabiting the pelagic zone of El Plateado (see Fig. 8 for field measures of zooplankters' body size), which means that it is potentially more vulnerable to invertebrate predators than the larger-bodied species (Kerfoot \& DeMott 1980, Gliwicz \& Pijanowska 1989).

The depth selection behavior of zooplankters, which includes some period of DVM, results in the exposure of the animals to a given set of environment variables such as light, food, temperature, and oxygen concentration. Here we searched for possible associations between the populations' distribution and water temperature and oxygen content. It is expectable that DVM carry some kind of cost, e.g. the energetic cost of swimming or to find low food availability in deep waters. Nevertheless the cost of swimming is considered to be of minor importance (Vlymen 1970, Alcaraz \& Strickler 1988, Dawidowicz \& Loose 1992a) and hypolimnetic food limitation is less likely in eutrophic systems like El Plateado. On the other hand, lower hypolimnetic temperature can drive a considerable lowering in developmental rates and therefore in the population growth rate (Bottrell 1975, Orcutt \& Porter 1983, Dawidowicz \& Loose 1992b). In addition to the cost attributable to low temperature, it is conceivable that hypoxic conditions of deep waters exert lethal and/or sublethal harmful effects on the exposed zooplankters (Hanazato 1992, Massana et al. 1994).

Our regression analyses suggest that, when DVM does not occur, there are no significant relation between depth-specific abundance of zooplankters and temperature or oxygen content (see Table 3). Conversely, under DVM, the three groups analyzed showed an inverse correlation with oxygen concentration when the zooplankters are closer to the surface, although some differences were detected between species. During DVM, D. chilense showed an inverse correlation with oxygen at day and a direct relation with the same variable at night. This suggest that this population might be paying a cost for performing DVM, whereas at night the group is preferentially located at high oxygen concentrations. $T$. diabolicus show a similar

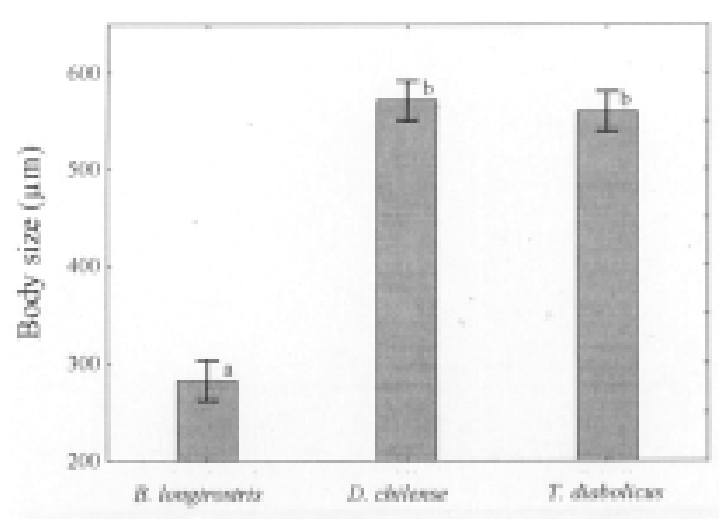

Fig. 8: Mean body size of zooplankters measured in the field during the period of study. Cladocerans measured from top of the head to the base of the spine, copepods measured from the top of the head to the base of furcal setae $\left(\mathrm{n}=210 \times 3\right.$, ANOVA: $\mathrm{F}_{2,627}=$ 244.30, $\mathrm{P}<0.0001)$. Error bars denote 0.95 confidence intervals, different letters above bars indicate significant differences between species (Tukey HSD test).

Tamaño corporal medio de los zooplancteres medido en terreno durante el periodo de estudio. Los cladóceros se midieron desde el techo de la cabeza hasta la base de la espina, los copépodos se midieron desde el techo de la cabeza hasta la base de las setas furcales $(n=210 \times 3$, ANDEVA: $\left.\mathrm{F}_{2,627}=244,30 ; \mathrm{P}<0,0001\right)$. Las barras de error indican intervalos de confianza 0,95; letras diferentes sobre las barras indican diferencias significativas entre especies (prueba de HSD de Tukey). 
pattern, but during night concentrates at higher temperature as well. The relation of $B$. longirostris and the physical environment is more elusive, since we found a significant (inverse) relation between oxygen and abundance only after the descending phase during the reverse DVM. Therefore $B$. longirostris distributes uniformly respect to the oxygen and temperature levels when it does not migrates, when it exhibit normal DVM, and during the day while show reverse DVM. In summary, our analyses reveal that the normal DVM of $D$. chilense and $T$. diabolicus, as well as the reverse DVM of $B$. longirostris determine the exposure of the zooplankter to low levels of oxygen concentration, supporting the importance of oxygen in eutrophic systems as a modulator of DVM and indirectly as a factor influencing the population dynamics. It should be noted, nevertheless, that less-severe hypoxic waters in metalimnion or hypolimnion can act as a refuge against fish, since zooplankters are more tolerant to low levels of oxygen (Zaret 1975, Shapiro 1990, Horppila et al. 2000). However, in our work we found consistently oxygen levels below $1 \mathrm{mgL}^{-1}$ after September, which is the tolerance limit for cladocerans (Shapiro 1990 and references therein).

By randomly permuting day vs. night distributions at each date, and calculating the changes in average exposure to temperature and oxygen, we obtained that DVM of $T$. diabolicus exert a reduction in mean body temperature and mean birth rate during the period AugustOctober (Fig.6). Bosmina longirostris was not affected by temperature changes at any time, and D. chilense experienced a temperature reduction only in September. On the other hand, mean oxygen levels experienced by zooplankton did change in all dates/species (except for B. longirostris in August, Fig. 7) as a consequence of DVM. Particularly strong results are those for September, October, and December, when all species showed significant DVM and significant reduction in oxygen levels when migrating downwards.

There is little doubt about the detrimental effects of lowering oxygen and temperature on the individual fitness and population growth rate of zooplankton. Therefore, we found clear field evidence that the observed DVM of the zooplankton community of lake El Plateado have associated costs derived at least from oxygen exposure and at a lesser extent from temperature. Our results, reviewed in relation to the hypotheses specified in the introduction section, reveals that (1) the three analyzed populations exhibit DVM; (2) that $T$. diabolicus and $D$. chilense exhibit the normal pattern of DVM, but that $B$. longirostris exhibits normal DVM at first and then switches to reverse DVM; and (3) that for all species and most dates, zooplankters experience significant decreases in oxygen exposure as a consequence of downward migration. Temperature costs are less important but present in T. diabolicus and $D$. chilense during part of the year.

To obtain a mechanistic explanation of the observed patterns, future work should deal with the functional relationship between oxygen reduction and survival and recruitment of zooplankton. Also, it is of major importance to quantify the diet preferences of fish and water mites throughout the seasons, and to accurately describe the population dynamics (in time and depth) of vertebrate and invertebrate predators, as well as changes in abundance, availability and quality of the resources.

\section{ACKNOWLEDGEMENTS}

This work was partially supported by Wolkswagen-Stiftung and Dirección de Postgrado of the Universidad Católica de Valparaíso. The manuscript was finished while R.R.J. was a post-doctoral fellow, FONDECYT grant 3000051. We thank L. A. Ebensperger for reviewing earlier versions of this manuscript.

\section{LITERATURE CITED}

ALCARAZ M \& JR STRICKLER (1988) Locomotion in copepods: pattern of movements and energetics of Cyclops. Hydrobiologia 167/168: 409-414.

ARAYA JM \& LR ZÚÑIGA (1985) Manual taxonómico del zooplancton lacustre de Chile. Boletín Informativo Limnológico, Universidad Austral de Chile 8: 1-110

BAHAMONDES I, I VILA \& D SOTO (1979) Hábitos alimentarios de los pejerreyes (Pisces: Atherinidae) del embalse Rapel, Chile. Medio Ambiente (Chile) 4: 3-18.

BOERSMA M, P SPAAK \& L DeMEESTER (1998) Predator-mediated plasticity in morphology, life history, and behavior of Daphnia: the uncoupling of responses. American Naturalist 152: 237-248.

BOTTRELL HH (1975) The relationship between temperature and duration of egg development in some epiphytic Cladocera and Copepoda from the river Thames. Reading, with a discussion of temperature functions. Oecologia 18: 63-68.

BOTTRELL HH, A DUNCAN, ZM GLIWICZ, E GRYGIEREK, A HERZIG, A HILLBRICHTILKOWSKA, H KURASAWA, P LARSSON \& T WEGLENSKA (1976) A review of some problems in zooplankton production studies. Norwegian Journal of Zoology 24: 419-456.

BURBRIDGE RG, MC CARRASCO \& PA BROWN (1973) Age, growth, lenght-weight relationship, sex ratio and food habits of the Argentine pejerrey, 
Basilichthys bonariensis (Cuv. and Val.) from lake Peñuelas, Valparaíso, Chile. Journal of Fish Biology 6: 229-305.

CALABAN MJ \& JC MAKAREWICZ (1982) The effect of temperature and density on the amplitude of vertical migration of Daphnia magna. Limnology and Oceanography 27: 262-271.

DAWIDOWICZ P (1994) Which is the most costly component in diel vertical migration of zooplankton? Internationale Vereinigung für Theoretische und Angewandte Limnologie 25: 2396-2399.

DAWIDOWICZ P \& CJ LOOSE (1992a) Cost of swimming by Daphnia during diel vertical migration. Limnology and Oceanography 37: 665-669.

DAWIDOWICZ P \& CJ LOOSE (1992b) Metabolic costs during predator-induced diel vertical migration of Daphnia. Limnology and Oceanography 37: 1589-1595.

DeMEESTER L, DAWIDOWICZ P, VAN GOOL E \& CJ LOOSE (1999) Ecology and evolution of predatorinduced behavior of zooplankton: depth selection behavior and diel vertical migration. In : Tollrian R \& CD Harvell (eds) The ecology and evolution of inducible defenses: 160-176. Princeton University Press, Princeton, New Jersey, USA.

DOMÍNGUEZ P, H MOLINA \& F SÁIZ (1981) Variaciones temporales de las condiciones químicas de una laguna eutrófica de régimen monomíctico templado. Anales del Museo de Historia Natural de Valparaíso (Chile) 14: 175-184.

DOMÍNGUEZ P, L ZÚÑIGA \& G LEMBEYE (1976) Condiciones químicas y físicas de la Laguna El Plateado, Chile. Noticiero Mensual del Museo Nacional de Historia Natural 29: 3-11.

ESCALANTE A (1983) Contribución al conocimiento de las relaciones tróficas de peces de agua dulce del Área Platense. Limnobios 6: 379-402.

FROST BW \& SM BOLLENS (1992) Variability of diel vertical migration in the marine planktonic copepod Pseudocalanus newmani in relation to its predators. Canadian Journal of Fisheries and Aquatic Sciences 49: $1137-1141$

GABRIEL W (1993) Models on diel vertical migration. Archiv für Hydrobiologie Beiheft 39: 123-136.

GELLER W (1986) Diurnal vertical migration of zooplankton in a temperate great lake (L. Constance): a starvation avoidance mechanism? Archiv für Hydrobiologie (Supplement) 74: 1-60

GLIWICZ ZM \& J PIJANOWSKA (1989) The role of predation in zooplankton succession: In: Sommer U (ed) Plankton ecology. Succession in plankton communities: 253-296. Springer-Verlag, Berlin, Germany.

GRIESHABER MK, I HARDEWIG, U KREUTZER, A SCHNEIDER \& S VÖLKEL (1992) Hypoxia and sulfide tolerance in some marine invertebrates. Verhandlungen der Deutschen Zoologischen Gesellschaft 85: 55-76.

GUISANDE C, A DUNCAN \& W LAMPERT (1991) Trade-offs in Daphnia vertical migration strategies. Oecologia 87: 357-359.

HANAZATO T (1992) Direct and indirect effects of lowoxygen layers on lake zooplankton communities. Archiv für Hydrobiologie Beiheft 35: 87-98.

HANEY JF \& DJ HALL (1973) Sugar-coated Daphnia: a preservation technique for Cladocera. Limnology and Oceanography 18: 331-333.

HOOD G (2002) Poptools version 2.4. Available on-line at http://www.cse.csiro.au/poptools.

HORPPILA J, T MALINEN, L NURMINEN, GP TALLBER \& M VINNI (2000) A metalimnetic oxygen minimum indirectly contributing to the low biomass of cladocerans in Lake Hiidenvesi - a diurnal study on the refuge effect. Hydrobiologia 436: 81-90.

HUTCHINSON GE (1967) A treatise on limnology, Volume 2: introduction to lake biology and the limnoplankton. Wiley \& Sons, New York, New York, USA. 1,115 pp.

KERFOOT WC \& WR DeMOTT (1980) Foundations for evaluating community interactions: the use of enclosures to investigate coexistence of Daphnia and Bosmina. In: Kerfoot WC (ed) Ecology and evolution of zooplankton communities: 725-741. University Press of New England, Hanover, New Hampshire, USA.

LAMPERT W (1989) The adaptive significance of diel vertical migration of zooplankton. Functional Ecology 3: 21-27.

LAMPERT W (1993) Ultimate causes of diel vertical migration of zooplankton: new evidence for the predator-avoidance hypothesis. Archiv für Hydrobiologie Beiheft 39: 79-88.

LAMPERT W, RD SCHMITT \& P MUCK (1988) Vertical migration of freshwater zooplankton: test of some hypotheses predicting a metabolic advantage. Bulletin of Marine Sciences 43: 620-640.

LOOSE CJ \& P DAWIDOWICZ (1994) Trade-offs in diel vertical migration by zooplankton: the costs of predator avoidance. Ecology 75: 2255-2263.

MANGEL M \& CW CLARK (1988) Dynamic modeling in behavioral ecology. Princeton University Press, Princeton, New Jersey, USA. 308 pp.

MANLY BFJ (1997) Randomization, bootstrap and Monte Carlo methods in biology. Second edition. Chapman \& Hall, London, United Kingdom. 399 pp.

MASSANA R, JM GASOL, K JÜRGENS \& C PEDRÓSALIÓ (1994) Impact of Daphnia pulex on a metalimnetic microbial community. Journal of Plankton Research 16: 1379-1399.

McCAULEY E (1984) The estimation of abundance and biomass of zooplankton in samples. In: Downing JA \& FH Rigler (eds) A manual of methods for the assessment of secondary production in fresh waters: 228-265. Blackwell Scientific Publications, Oxford, United Kingdom.

MONTECINO V \& S CABRERA (1984) Limnological pilot project for the characterization of temperate lakes in Central Chile. Internationale Vereinigung für Theoretische und Angewandte Limnologie 22: 1332-1334

OHMAN MD \& BW FROST (1983) Reverse diel vertical migration: an escape from invertebrate predators. Science 220: 1404-1407.

ORCUTT JD Jr. \& KG PORTER (1983) Diel vertical migration by zooplankton: Constant and fluctuating temperature affects life history parameters of Daphnia. Limnology and Oceanography 24: 781-782.

PALOHEIMO JE (1974) Calculation of instantaneous birth rate. Limnology and Oceanography 19: 692-694.

RAMOS-JILIBERTO R \& LR ZÚNIIGA (2001) Depthselection patterns and diel vertical migration of Daphnis ambigua (Crustacea: Cladocera) in lake El Plateado. Revista Chilena de Historia Natural 74: 573-585.

RAMOS-JILIBERTO R, C TRAPP, F FLORES, A BRIGNARDELLO, O SIEBECK \& L ZÚÑIGA (1998) Seasonal succession of planktonic crustaceans in a small eutrophic temperate lake (E1 Plateado, Valparaíso, Chile). Internationale Vereinigung für Theoretische und Angewandte Limnologie 26: 1997-2000. 
RAMOS-JILIBERTO R, F FLORES, C TRAPP, O SIEBECK \& L ZÚÑ̃IGA (1997) Thermal, light and oxygen characteristics in a small eutrophic warm monomictic lake (El Plateado, Valparaíso, Chile). Internationale Vereinigung für Theoretische und Angewandte Limnologie 26: 256-260

RINGELBERG J (1991) A mechanism of predator-mediated induction of diel vertical migration in Daphnia hyalina. Journal of Plankton Research 13: 83-89.

RINGELBERG J, BJG FLIK, D LINDENAAR \& $\mathrm{K}$ ROYACKERS (1991) Diel vertical migration of Daphnia hyalina (sensu latiori) in lake Maarsseveen: part 1. Aspects of seasonal and daily timing. Archiv für Hydrobiologie 121: 129-145.

SHAPIRO J (1990) Biomanipulation: the next phasemaking it stable. Hydrobiologia 200/201: 13-27.

SOLOW AR, SM BOLLENS \& A BEET (2000) Comparing two vertical plankton distributions. Limnology and Oceanography 45: 506-509.

STICH HB \& W LAMPERT (1981) Predator evasion as an explanation of diurnal vertical migration by zooplankton. Nature 293: 396-398.

STICH HB \& W LAMPERT (1984) Growth and reproduction of migrating and non-migrating
Daphnia species under simulated food and temperature conditions of diurnal vertical migration. Oecologia 61: 192-196.

TOLLRIAN R \& SI DODSON (1999) Inducible defenses in Cladocera: constraints, costs, and multipredator environments. In: Tollrian R \& CD Harvell (eds) The ecology and evolution of inducible defenses: 177-202. Princeton University Press, Princeton, New Jersey, USA.

VLYMEN WJ (1970) Energy expenditure by swimming copepods. Limnology and Oceanography 15 : 348-356.

VON ELERT E \& CJ LOOSE (1996) Predator-induced diel vertical migration in Daphnia: Enrichment and preliminary chemical characterization of a kairomone exuded by fish. Journal of Chemical Ecology 22: 885-895.

ZARET T (1975) Strategies for existence of zooplankton prey in homogeneous environments. Internationale Vereinigung für Theoretische und Angewandte Limnologie 19: 1484-1489.

ZARET TM \& JS SUFFERN (1976) Vertical migration in zooplankton as a predator avoidance mechanism. Limnology and Oceanography 21: 804-813. 


\section{APPENDIX 1}

Depth-specific relative abundances of zooplankters at noon (D) and midnight $(\mathrm{N})$ over the study period

Abundancias relativas profundidad-específicas de zooplanctontes a mediodía (D) y medianoche (N) a lo largo del periodo de estudio

\begin{tabular}{|c|c|c|c|c|c|c|c|c|c|c|c|c|c|c|}
\hline \multirow[b]{2}{*}{ Depth } & \multicolumn{2}{|c|}{ April } & \multicolumn{2}{|c|}{ July } & \multicolumn{2}{|c|}{ August } & \multicolumn{2}{|c|}{ September } & \multicolumn{2}{|c|}{ October } & \multicolumn{2}{|c|}{ December } & \multicolumn{2}{|c|}{ January } \\
\hline & $\mathrm{D}$ & $\mathrm{N}$ & $\mathrm{D}$ & $\mathrm{N}$ & $\mathrm{D}$ & $\mathrm{N}$ & $\mathrm{D}$ & $\mathrm{N}$ & $\mathrm{D}$ & $\mathrm{N}$ & $\mathrm{D}$ & $\mathrm{N}$ & $\mathrm{D}$ & $\mathrm{N}$ \\
\hline
\end{tabular}

T. diabolicus

\begin{tabular}{|c|c|c|c|c|c|c|c|c|c|c|c|c|c|c|}
\hline 0 & 0.012 & 0.173 & 0.019 & 0.079 & 0.009 & 0.05 & 0.007 & 0.095 & 0.006 & 0.127 & 0.065 & 0.21 & 0.043 & 0.093 \\
\hline 1 & 0.018 & 0.213 & 0.04 & 0.13 & 0.032 & 0.141 & 0.011 & 0.104 & 0.008 & 0.203 & 0.127 & .175 & 0.041 & 0.186 \\
\hline$?$ & 0.008 & 0.103 & 0.096 & 0.123 & 0.075 & 0.122 & 0.045 & 0.277 & 0.027 & 0.221 & 0.109 & 0.198 & 0.122 & 0.163 \\
\hline & 0.065 & 0.089 & 0.173 & 0.145 & 0.192 & 0.143 & 0.146 & 0.127 & 0.175 & 0.209 & 0.161 & 0.095 & 0.02 & 0.186 \\
\hline 4 & 0.044 & 0.068 & 0.189 & 0.174 & 0.137 & 0.144 & 0.23 & 0.133 & 0.435 & 0.059 & 0.182 & 0.141 & 0.204 & 0.07 \\
\hline 5 & 0.043 & 0.101 & 0.151 & 0.139 & 0.242 & 0.124 & 0.237 & 0.137 & 0.149 & 0.06 & 0.104 & 0.07 & 0.285 & 0.093 \\
\hline & 0.651 & 0.126 & 0.157 & 0.099 & 0.138 & 0.135 & 0.197 & 0.05 & 0.053 & 0.055 & 0.149 & 0.072 & 0.163 & 0.047 \\
\hline & 0.159 & 0.126 & 0.175 & 0.111 & 0.176 & 0.14 & 0.127 & 0.077 & 0.147 & 0.068 & 0.103 & 0.04 & 0.122 & 0.163 \\
\hline
\end{tabular}

B. longirostris

\begin{tabular}{|c|c|c|c|c|c|c|c|c|c|c|c|c|c|c|}
\hline 0 & 0.028 & 0.097 & 0.285 & 0.168 & 0.057 & 0.131 & 0.04 & 0.169 & 0.033 & 0.023 & 0.106 & 0.081 & 0.024 & 0.036 \\
\hline 1 & 0.084 & 0.189 & 0.211 & 0.087 & 0.182 & 0.264 & 0.201 & 0.271 & 0.091 & 0.034 & 0.173 & 0.111 & 0.107 & 0.08 \\
\hline 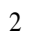 & 0.124 & 0.123 & 0.197 & 0.327 & 0.292 & 0.432 & 0.252 & 0.249 & 0.198 & 0.04 & 18 & 085 & 193 & .098 \\
\hline & 0.196 & 0.193 & 0.11 & 0.118 & 0.282 & 0.094 & 0.119 & 0.168 & 0.182 & 0.077 & 0.176 & 0.181 & 0.123 & 0.152 \\
\hline & 0.142 & 0.134 & 0.031 & 0.051 & 0.048 & 0.029 & 0.163 & 0.055 & 0.224 & 0.29 & 0.167 & 0.113 & 0.102 & 0.274 \\
\hline 5 & 0.146 & 0.134 & 0.058 & 0.065 & 0.034 & 0.035 & 0.085 & 0.031 & 0.133 & 0.172 & 0.066 & 0.153 & 0.182 & 0.153 \\
\hline & 0.219 & 0.076 & 0.049 & 0.047 & 0.04 & 0.012 & 0.077 & 0.019 & 0.048 & 0.233 & 0.079 & 0.091 & 0.183 & 0.118 \\
\hline & 0.062 & 0.054 & 0.059 & 0.137 & 0.065 & 0.003 & 0.062 & 0.038 & 0.091 & 0.132 & 0.053 & 0.185 & 0.087 & 0.089 \\
\hline
\end{tabular}

\section{D. chilense}

\begin{tabular}{|c|c|c|c|c|c|c|c|c|}
\hline 0 & 0 & 0.038 & 0.034 & 0.278 & 0.035 & 0.102 & 0.09 & 0.089 \\
\hline 1 & 0 & 0.231 & 0 & 0.333 & 0.026 & 0.12 & 0.152 & 0.067 \\
\hline 2 & 0 & 0.615 & 0 & 0.167 & 0.042 & 0.14 & 0 & 0.022 \\
\hline 3 & 0.069 & 0.077 & 0.345 & 0.167 & 0.064 & 0.139 & 0.038 & 0.067 \\
\hline 4 & 0.414 & 0.038 & 0.345 & 0 & 0.191 & 0.15 & 0.303 & 0.133 \\
\hline 5 & 0.207 & 0 & 0.138 & 0 & 0.219 & 0.106 & 0.303 & 0.089 \\
\hline 7 & 0.138 & 0 & 0.138 & 0 & 0.237 & 0.087 & 0 & 0.178 \\
\hline 8.5 & 0.172 & 0 & 0 & 0.056 & 0.187 & 0.156 & 0.114 & 0.356 \\
\hline
\end{tabular}

